\title{
A Genetically Encoded Fluorosulfonyloxybenzoyl-L-lysine for Expansive Covalent Bonding of Proteins via SuFEx Chemistry
}

\author{
Jun Liu ${ }^{1 \ddagger}$, Li Cao ${ }^{1 \ddagger}$, Paul C. Klauser ${ }^{1}$, Rujin Cheng ${ }^{2}$, Viktoriya Y. Berdan¹, Wei Sun ${ }^{1}$, Nanxi \\ Wang ${ }^{1}$, Farid Ghelichkhani ${ }^{2}$, Bingchen $\mathrm{Yu}^{1}$, Sharon Rozovsky ${ }^{2}$, and Lei Wang ${ }^{1 *}$
}

1. University of California San Francisco, Department of Pharmaceutical Chemistry and the Cardiovascular Research Institute, 555 Mission Bay Blvd. South, San Francisco, California 94158, United States

2. University of Delaware, Department of Chemistry and Biochemistry, Newark, Delaware 19716, United States

*E-mail: Lei.wang2@ucsf.edu

‡ These authors contributed equally to this work. 


\section{Table of Contents}

1. Experimental procedures

a) Supplementary table 1: Primers used for cloning

b) Reagents and molecular biology

c) Chemical synthesis of FSK

d) Library construction and FSKRS mutant selection

e) Incorporation of FSK into EGFP (182TAG), sfGFP (182TAG)

f) General incorporation of FSK into proteins for expression and purification

g) Utilization of FSK and FSY into ecGST, sjGST and their mutants for protein cross-linking in $\mathrm{E}$. coli

h) In vitro cross-linking of 7D12 and EGFR

i) In cellular cross-linking of 7D12 and EGFR

j) Genetic incorporation of FSK into Hela GFP (182TAG)

k) Genetic incorporation of FSK into ecGST mutants in mammalian cells

l) Mass spectrometry

2. Supplementary figures

Figure S1. Comparison of FSK incorporation efficiency into EGFP at $18{ }^{\circ} \mathrm{C}$ for $24 \mathrm{~h}$

Figure S2. Comparison of FSK incorporation efficiency into EGFP at $30^{\circ} \mathrm{C}$ for $6 \mathrm{~h}$

Figure S3. Western blot analysis of incorporation of FSK into EGFP (182TAG)

Figure S4. Incorporation of FSK into sfGFP (2TAG) and sfGFP(151TAG)

Figure S5. $\mathrm{M} / \mathrm{Z}$ mass spectrum of Ub (6FSK)

Figure S6. Comparison of the FSY and FSK mediated GST cross-linking in short distance proximity

Figure S7. Comparison of the FSY and FSK mediated E. coli GST cross-linking at site 86

Figure S8. Comparison of the cross-linking efficiency of FSK and FSY in mediating Trx and PAPS (aka CysH) cross-linking

Figure S9. Tandem mass spectrum of the intact FSK-incorporated peptide of ubiquitin

Figure S10. SDS-PAGE analysis of purified nanobody 7D12 (31FSK)

Figure S11. SDS-PAGE and Western blot analysis of covalent cross-linking of nanobody 7D12 (WT) and 7D12 (31FSK) with EGFR in vitro

Figure S12. Tandem mass spectra of cross-linked peptides identified from Trx (62FSK). Figure S13. Tandem mass spectra of cross-linked peptides identified from Trx (62FSY). 


\section{Experimental Procedures:}

\section{Supplementary table 1: Primers used for cloning}

\begin{tabular}{|c|c|}
\hline Primer & Oligonucleotide Sequence $\left(5^{\prime} \rightarrow 3^{\prime}\right)$ \\
\hline MaPyIRS Ndel & GTTGTTCATATGACCGTGAAGTACACCGACGCCCAG \\
\hline 126/129-Rev & CAGGTTTGGCGCCAGCATCGGGCG \\
\hline 126/129-For & CGCCCGATGCTGGCGCCAAACCTGNNKAGCGTGNNKCGTGACCTGCGCGATCACACCGAC \\
\hline 166-Rev & CAGCATGGTGAACTCCTCCAG \\
\hline 166/168-For & CTGGAGGAGTTCACCATGCTGNNKCTGNNKGATATGGGTCCGCGCGGCGAC \\
\hline 227-Rev & GACCCACAGCCGCGCTGCACACTTCCTGACCGTTAATTTCCACGTCGATG \\
\hline 227/228/229-For & GTGTGCAGCGCGGCTGTGGGTCCANNKNNKNNKGATGCGGCCCATGACGTGCATGAGCCG \\
\hline MaPyIRS Pstl & GGTGGtCTGCAGTTAATTGATTTTGGGCACCATTCAGGTAG \\
\hline sfGFP2TAG-For & GGTGGTCATATGTAGAAGGGCGAGGAGCTGTTCAC \\
\hline sfGFP2TAG-Rev & GTTGTTAAGCTTTTAGTGATGGTGATGGTGATGGCTGCCCTTGTACAGCTCGTCCATG \\
\hline HRpNEUmaRS-For & GAGACCCAAGCTGGCTAGCGCCACCATGACCGTGAAGTACACCGACGC \\
\hline HRpNEUmaRS_Rev & GGCTGATCAGCGGGTTTAAAGCGGCCGCTTAATTGATTTTGGCACCATTC \\
\hline ecGST Ndel & GTTGTTCATATGAAATTGTTCTACAAACCGGGTGCCTGC \\
\hline ecGST HindIII & GTTGTTAAGCTTTTAATGGTGATGGTGATGGTGCTTTAAGCCTTCCGCTGACAG \\
\hline ecGST86TAG-For & GACCGCCAGTTGCTGGCACCGTAGAACAGTATTTCCCGCTATAAAAC \\
\hline ecGST86TAG-Rev & GTTTTATAGCGGGAAATACTGTTCTACGGTGCCAGCAACTGGCGGTC \\
\hline ecGST86TAG92A-For & GCACCGTAGAACAGTATTTCCCGCGCTAAAACCATCGAATGGCT \\
\hline ecGST86TAG92A-Rev & GCGCGGGAAATACTGTTCTACGGTGCCAGCAACTGGCGGTCGGG \\
\hline $\begin{array}{l}\text { ecGST86TAG92A72A- } \\
\text { For }\end{array}$ & TGACGGAAGGCGTAGCGATTATGCAGGCTCTTGCCGACAGCGTCCCCGA \\
\hline $\begin{array}{l}\text { ecGST86TAG92A72A- } \\
\text { For }\end{array}$ & GCCTGCATAATCGCTACGCCTTCCGTCAGCAAAGTACCGTCATCCA \\
\hline ecGST65TAG-For & CTGCTGGATGACGGTACTTTGCTGACGTAGGGCGTAGCGATTATGCAGTAT \\
\hline ecGST65TAG-Rev & CTACGTCAGCAAAGTACCGTCATCCAGCAGCAATGCAGGCACCTGCCCCTT \\
\hline HR-sjGST Ndel & CTTTAAGAAGGAGATATACATATGACTAGTATGTCCCCTATACTAG \\
\hline HR-sjGST HindlII & $\begin{array}{l}\text { CCGCCAAAACAGCCAAGCTTTTAGTGATGGTGATGGTGATGGGATCCACGCGGAACCAGAT } \\
\text { CCG }\end{array}$ \\
\hline sjGST97TAG-For & GATTTCAATGCTTGAAGGAtagGTTTTGGATATTAGATACGGTG \\
\hline sjGST97TAG-Rev & CACCGTATCTAATATCCAAAACctaTCCTTCAAGCATTGAAATC \\
\hline sjGST44A-For & GTGATAAATGGCGAAACAAAgcgTTTGAATTGGGTTTGGAGTTTC \\
\hline sjGST44A-Rev & GAAACTCCAAACCCAATTCAAAcgCTTTGTTTCGCCATTTATCAC \\
\hline ecGST Hindlll-pCDNA & GTTGTTAAGCTTGCCACCATGAAATTGTTCTACAAACCGGGTG \\
\hline ecGST Xhol-pCDNA & GGTGGTCTCGAGTTAATGGTGATGGTGATGGTGCTTTAAG \\
\hline sjGST44S-For & TGAAGGTGATAAATGGCGAAACAAATCGTTTGAATTGGGTTTGGAG \\
\hline sjGST44S-Rev & GATTTGTTTCGCCATTTATCACCTTCATCGCGCTCATACAAATGC \\
\hline sjGST44T-For & TGAAGGTGATAAATGGCGAAACAAAACGTTTGAATTGGGTTTGGAG \\
\hline sjGST44T-Rev & GTTTTGTTTCGCCATTTATCACCTTCATCGCGCTCATACAAATGC \\
\hline sjGST44Y-For & GATGAAGGTGATAAATGGCGAAACAAATATTTTGAATTGGGTTTGGAGTT \\
\hline sjGST44Y-Rev & ATATTTGTTTCGCCATTTATCACCTTCATCGCGCTCATACAAATGCTC \\
\hline sjGST44H-For & GATGAAGGTGATAAATGGCGAAACAAACACTTTGAATTGGGTTTGGAGTT \\
\hline sjGST44H-Rev & GTGTTTGTTTCGCCATTTATCACCTTCATCGCGCTCATACAAATGCTC \\
\hline HRpEVOL-For & CTAACAGGAGGAATTACTAGTATGACCGTGAAGTACACCGAC \\
\hline HRpEVOL-Rev & CAATGATGATGATGATGATGGTCGACTTAATTGATTTTGGCACCATTC \\
\hline 7D12 Ndel & TAAGAAGGAGATATACATATGAAATACCTGCTGCCGACCG \\
\hline 7D12 Hindlll & TCCGCCAAAACAGCCAAGCTTTTAGTGGTGGTGGTGATGATGGGACGAGA \\
\hline 7D12 30TAG-For & TGACCTGTGCTGCGAGCGGCCGTACCAGCTAGAGCTACGGCATGGGTTGGTTT \\
\hline 7D12 30TAG-Rev & CTAGCTGGTACGGCCGCTCGCAGCACAGGTCAAACGGAGACTGCCACCGGTT \\
\hline 7D12 31TAG-For & CCTGTGCTGCGAGCGGCCGTACCAGCCGCTAGTACGGCATGGGTTGGTTTCGT \\
\hline 7D12 31TAG-Rev & CTAGCGGCTGGTACGGCCGCTCGCAGCACAGGTCAAACGGAGACTGCCACCG \\
\hline 7D12 109TAG-For & TTCTGCCTGGTATGGCACTCTGTAGGAATACGACTACTGGGG \\
\hline 7D12 109 TAG-Rev & CTACAGAGTGCCATACCAGGCAGAACCCGCCGCCGCGGCGCA \\
\hline
\end{tabular}




\section{Reagents and molecular biology}

Primers were synthesized and purified by Integrated DNA Technologies (IDT), and plasmids were sequenced by GENEWIZ. All molecular biology reagents were either obtained from New England Biolabs or Vazyme. His-HRP antibody, GFP monoclonal antibodies, GAPDH-HRP antibody were obtained from ProteinTech Group. pBAD-ubiquitin (6TAG) and pBAD-ecGST WT and ecGST mutants were used as previously described ${ }^{1}$. ecGST HindIII-pCDNA and ecGST Xhol-pCDNA primers were used to clone ecGST WT and ecGST (86TAG), ecGST (86TAG/92A), ecGST (86TAG/92A/72A) into pCDNA 3.1.

FSKRS amino acid sequence

MTVKYTDAQIQRLREYGNGTYEQKVFEDLASRDAAFSKEMSVASTDNEKKIKGMIANPSRHGL TQLMNDIADALVAEGFIEVRTPIFISKDALARMTITEDKPLFKQVFWIDEKRALRPMLAPNLGSVA RDLRDHTDGPVKIFEMGSCFRKESHSGMHLEEFTMLNLFDMGPRGDATEVLKNYISVVMKAA GLPDYDLVQEESDVYKETIDVEINGQEVCSAAVGPTPIDAAHDVHEPWSGAGFGLERLLTIREK YSTVKKGGASISYLNGAKIN

Red: mutated residues.

sfGFP (2TAG)

Primers sfGFP2TAG For and sfGFP2TAG Rev were used to construct pBAD-sfGFP (2TAG)

MXKGEELFTGVVPILVELDGDVNGHKFSVRGEGEGDATNGKLTLKFICTTGKLPVPWPTLVTTL TYGVQCFSRYPDHMKRHDFFKSAMPEGYVQERTISFKDDGTYKTRAEVKFEGDTLVNRIELKG IDFKEDGNILGHKLEYNFNSHNVYITADKQKNGIKANFKIRHNVEDGSVQLADHYQQNTPIGDG PVLLPDNHYLSTQSVLSKDPNEKRDHMVLLEFVTAAGITHGMDELYKGSHHHHHH

Red: amber codon TAG at $2^{\text {nd }}$ position.

ecGST (86TAG)

Primers ecGST Ndel to GST86TAG-Rev were used to construct pBAD-ecGST (86TAG) by overlap PCR.

MKLFYKPGACSLASHITLRESGKDFTLVSVDLMKKRLENGDDYFAVNPKGQVPALLLDDGTLLT EGVAIMQYLADSVPDRQLLAPXNSISRYKTIEWLNYIATELHKGFTPLFRPDTPEEYKPTVRAQL EKKLQYVNEALKDEHWICGQRFTIADAYLFTVLRWAYAVKLNLEGLEHIAAFMQRMAERPEVQ DALSAEGLKHHHHHH

Red: amber codon TAG at $86^{\text {th }}$ position.

ecGST (65TAG)

pBAD-ecGST (65TAG) was constructed by site-directed mutagenesis with primers ecGST65TAG-For and ecGST65TAG-Rev

MKLFYKPGACSLASHITLRESGKDFTLVSVDLMKKRLENGDDYFAVNPKGQVPALLLDDGTLLT XGVAIMQYLADSVPDRQLLAPVNSISRYKTIEWLNYIATELHKGFTPLFRPDTPEEYKPTVRAQL EKKLQYVNEALKDEHWICGQRFTIADAYLFTVLRWAYAVKLNLEGLEHIAAFMQRMAERPEVQ DALSAEGLKHHHHHH

Red: amber codon TAG at $65^{\text {th }}$ position. 
ecGST (86TAG/92A)

pBAD-ecGST (86TAG/92A) was constructed by site-directed mutagenesis with primers ecGST86TAG92A-For and ecGST86TAG92A-Rev

MKLFYKPGACSLASHITLRESGKDFTLVSVDLMKKRLENGDDYFAVNPKGQVPALLLDDGTLLT EGVAIMQYLADSVPDRQLLAPXNSISRAKTIEWLNYIATELHKGFTPLFRPDTPEEYKPTVRAQL EKKLQYVNEALKDEHWICGQRFTIADAYLFTVLRWAYAVKLNLEGLEHIAAFMQRMAERPEVQ DALSAEGLKHHHHHH

Red: amber codon TAG at $86^{\text {th }}$ position. Blue: $92 \mathrm{~A}$.

ecGST (86TAG/92A/72A)

pBAD-ecGST (86TAG/92A/72A) was constructed by site-directed mutagenesis with primers ecGST86TAG92A72A-For and ecGST86TAG92A72A-Rev

MKLFYKPGACSLASHITLRESGKDFTLVSVDLMKKRLENGDDYFAVNPKGQVPALLLDDGTLLT EGVAIMQALADSVPDRQLLAPXNSISRAKTIEWLNYIATELHKGFTPLFRPDTPEEYKPTVRAQL EKKLQYVNEALKDEHWICGQRFTIADAYLFTVLRWAYAVKLNLEGLEHIAAFMQRMAERPEVQ DALSAEGLKHHHHHH

Red: amber codon TAG at $86^{\text {th }}$ position. Blue: $72 / 92 \mathrm{~A}$.

sjGST WT

pBAD-sjGST WT was cloned with primers HR-sjGST Ndel and HR-sjGST HindIII.

MTSMSPILGYWKIKGLVQPTRLLLEYLEEKYEEHLYERDEGDKWRNKKFELGLEFPNLPYYIDG DVKLTQSMAIIRYIADKHNMLGGCPKERAEISMLEGAVLDIRYGVSRIAYSKDFETLKVDFLSKLP EMLKMFEDRLCHKTYLNGDHVTHPDFMLYDALDVVLYMDPMCLDAFPKLVCFKKRIEAIPQIDK YLKSSKYIAWPLQGWQATFGGGDHPPKSDLVPRGSHHHHHH

sjGST (97TAG) and sjGST (97TAG/44 mutants) pBAD-sjGST (97TAG) and pBAD-sjGST (97TAG/44A) were constructed by primers HR-sjGST Ndel, sjGST sjGST97TAG-For, sjGST97TAG-Rev, HR-sjGST Hindlll rev, sjGST44A-For, and sjGST44A-Rev. And primers set 44S-For, 44S-Rev, 44T-For, 44T-Rev, 44Y-For, 44Y-Rev, 44HFor, 44H-Rev were used to prepare pBAD-sjGST (97TAG/44S), pBAD-sjGST (97TAG/44T), pBAD-sjGST (97TAG/44Y) and pBAD-sjGST (97TAG/44H).

MTSMSPILGYWKIKGLVQPTRLLLEYLEEKYEEHLYERDEGDKWRNKKFELGLEFPNLPYYIDG DVKLTQSMAIIRYIADKHNMLGGCPKERAEISMLEGXVLDIRYGVSRIAYSKDFETLKVDFLSKLP EMLKMFEDRLCHKTYLNGDHVTHPDFMLYDALDVVLYMDPMCLDAFPKLVCFKKRIEAIPQIDK YLKSSKYIAWPLQGWQATFGGGDHPPKSDLVPRGSHHHHHH

Red: amber codon TAG at $97^{\text {th }}$ position. Blue: Paired Lys 44 and its mutation to A, S, T, H, Y.

7D12 WT

Primers 7D12 Ndel and 7D12 Hindlll were used to clone 7D12 WT to pBAD plasmid.

MGQVKLEESGGGSVQTGGSLRLTCAASGRTSRSYGMGWFRQAPGKEREFVSGISWRGD STGYADSVKGRFTISRDNAKNTVDLQMNSLKPEDTAIYYCAAAAGSAWYGTLYEYDYWGQ GTQVTVSSHHHHHH

7D12 (30TAG)

pBAD-7D12 (30TAG) was constructed by site-directed mutagenesis with primers 7D12 30TAGFor and 7D12 30TAG-Rev 
MGQVKLEESGGGSVQTGGSLRLTCAASGRTSXSYGMGWFRQAPGKEREFVSGISWRGD STGYADSVKGRFTISRDNAKNTVDLQMNSLKPEDTAIYYCAAAAGSAWYGTLYEYDYWGQ GTQVTVSSHHHHHH

Red: amber codon TAG at $30^{\text {th }}$ position.

7D12 (31TAG)

pBAD-7D12 (31TAG) was constructed by site-directed mutagenesis with primers 7D12 31TAGFor and 7D12 31TAG-Rev

MGQVKLEESGGGSVQTGGSLRLTCAASGRTSRXYGMGWFRQAPGKEREFVSGISWRGD STGYADSVKGRFTISRDNAKNTVDLQMNSLKPEDTAIYYCAAAAGSAWYGTLYEYDYWGQ GTQVTVSSHHHHHH

Red: amber codon TAG at $31^{\text {st }}$ position.

\section{Chemical Synthesis of FSK}

Synthesis of aryl fluorosulfates was based on recent methods to synthesize sulfur (IV) fluorides using [4-(acetylamino)phenyl]imidodisulfuryl difluoride (AISF) reagent. ${ }^{2}$

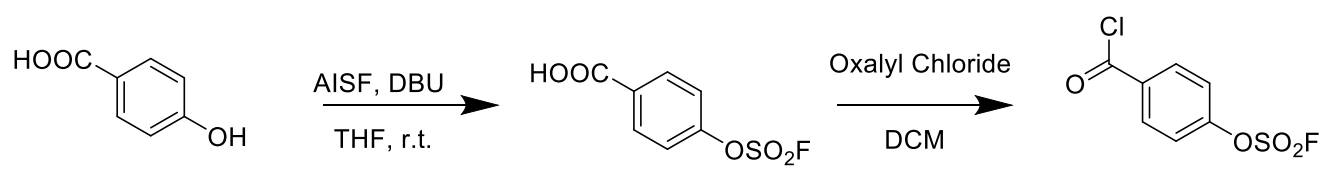

1

2

3

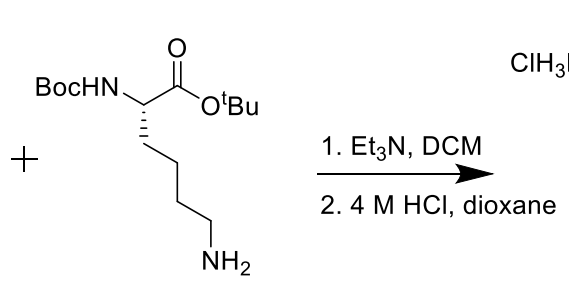

4

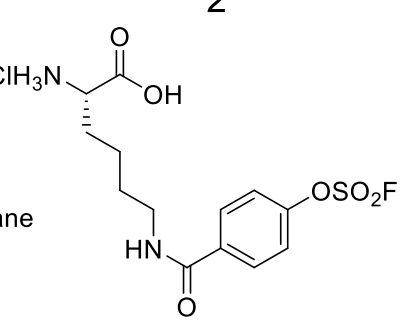

5

Synthesis of 4-((fluorosulfonyl)oxy)benzoic acid (2). To a $200 \mathrm{~mL}$ round-bottom flask were added 4-hydroxybenzoic acid $(1,1.38 \mathrm{~g}, 10 \mathrm{mmol})$ and [4-(acetylamino)phenyl]imidodisulfuryl difluoride (AISF) reagent ( $3.78 \mathrm{~g}, 12 \mathrm{mmol}, 1.2$ equiv.). The mixture was dissolved in $50 \mathrm{~mL}$ anhydrous tetrahydrofuran and 1,8-diazabicyclo[5.4.0]undec-7-ene (3.35 mL, $22 \mathrm{mmol}, 2.2$ equiv.) was added dropwise while stirring. The solution was then stirred at r.t. for 20 minutes. The reaction was then diluted with $50 \mathrm{~mL}$ ethyl acetate and washed with $1 \mathrm{M} \mathrm{HCl}(100 \mathrm{~mL} \times 2)$ and brine $(100$ $\mathrm{mL} \times 1$ ). The organic fraction was dried with anhydrous sodium sulfate and concentrated under vacuum. The crude product was then purified by column chromatography using $\mathrm{MeOH}: \mathrm{CH}_{2} \mathrm{Cl}_{2}$ (1:100). The product, 4-(fluorosulfonyl)oxy)benzoic acid, was isolated as a white solid $(2,1.72 \mathrm{~g}$, $7.8 \mathrm{mmol}, 78 \%)$.

Synthesis of fluorosulfonyloxybenzoyl-L-lysine (5, FSK). To a stirred solution of 4((fluorosulfonyl)oxy)benzoic acid $(2,0.22 \mathrm{~g}, 1 \mathrm{mmol})$ in dry $\mathrm{CH}_{2} \mathrm{Cl}_{2}(15 \mathrm{~mL})$ was added oxalyl chloride $(0.21 \mathrm{ml}, 2.5 \mathrm{mmol}, 2.5$ equiv. $)$ dropwise under argon at $0^{\circ} \mathrm{C}$. Dimethylformamide $(0.1$ $\mathrm{mL}$ ) was then added as catalyst. The reaction mixture was then stirred at r.t. for 5 hours. The 
solution was then concentrated under vacuum resulting in a yellow oil. The crude 4(chlorocarbonyl)phenyl sulfofluoridate $(3, \sim 1 \mathrm{mmol})$ was redissolved in dry $\mathrm{CH}_{2} \mathrm{Cl}_{2}(10 \mathrm{~mL})$ and cooled to $0^{\circ} \mathrm{C}$. N-Boc-Lys- ${ }^{t} \mathrm{Bu}\left(4,0.34 \mathrm{~g}, 1 \mathrm{mmol}, 1\right.$ equiv.) was then added, after which $\mathrm{Et}_{3} \mathrm{~N}(0.15$ $\mathrm{mL}, 1.1 \mathrm{mmol}, 1.1$ equiv.) was added dropwise. The reaction mixture was stirred at r.t. overnight. The reaction was quenched with $20 \mathrm{~mL}$ of $\mathrm{H}_{2} \mathrm{O}$ and washed with $1 \mathrm{M} \mathrm{HCl}(20 \mathrm{~mL} \times 2)$. The aqueous phase was combined and extracted with ethyl acetate $(20 \mathrm{~mL} \times 2)$. The organic fractions were combined and dried over anhydrous sodium sulfate and concentrated under vacuum. The crude product was then purified by column chromatography using $\mathrm{MeOH}: \mathrm{CH}_{2} \mathrm{Cl}_{2}(1: 100)$. The product, N-Boc-FSK- ${ }^{-} \mathrm{Bu}$, was isolated as a yellow oil $(0.25 \mathrm{~g}, 0.50 \mathrm{mmol}, 50 \%)$.

$\mathrm{N}$-Boc-FSK-'Bu $(0.25 \mathrm{~g}, 0.50 \mathrm{mmol})$ was added to a scintillation vial and dissolved in $4 \mathrm{M}$ $\mathrm{HCl}$ in dioxane $(10 \mathrm{~mL})$. The reaction was stirred overnight. The resultant solid was filtered off and washed with cool ether $(10 \mathrm{~mL} \times 2)$ affording the product $\mathrm{FSK}-\mathrm{HCl}$ as a white solid $(5,158$ $\mathrm{mg}, 0.41 \mathrm{mmol}, 81 \%$ )

${ }^{1} \mathrm{H}$ NMR (400 MHz, $\left.\mathrm{D}_{2} \mathrm{O}\right): \delta(\mathrm{ppm}) 7.89(\mathrm{~d}, J=8.8 \mathrm{~Hz}, 2 \mathrm{H}), 7.59(\mathrm{~d}, J=8.8 \mathrm{~Hz}, 2 \mathrm{H}), 3.99(\mathrm{t}, J=$ $6.0,1 \mathrm{H}), 3.43(\mathrm{t}, J=6.8 \mathrm{~Hz}, 2 \mathrm{H}), 2.03-1.94(\mathrm{~m}, 2 \mathrm{H}), 1.72-1.66(\mathrm{~m}, 2 \mathrm{H}), 1.55-1.49(\mathrm{~m}, 2 \mathrm{H})$

${ }^{13} \mathrm{C}$ NMR $\left(100 \mathrm{MHz}, \mathrm{D}_{2} \mathrm{O}\right): \delta(\mathrm{ppm}) 173.5,169.9,152.4,135.2,130.2,121.9,53.9,40.1,30.2$, $28.5,22.3$

HR-ESI (+) m/z: calculated for $\mathrm{C}_{13} \mathrm{H}_{17} \mathrm{FN}_{2} \mathrm{NaO}_{6} \mathrm{~S}[\mathrm{M}+\mathrm{Na}]^{+}, 371.0684$; found 371.0690 .

${ }^{1} \mathrm{H}$ NMR
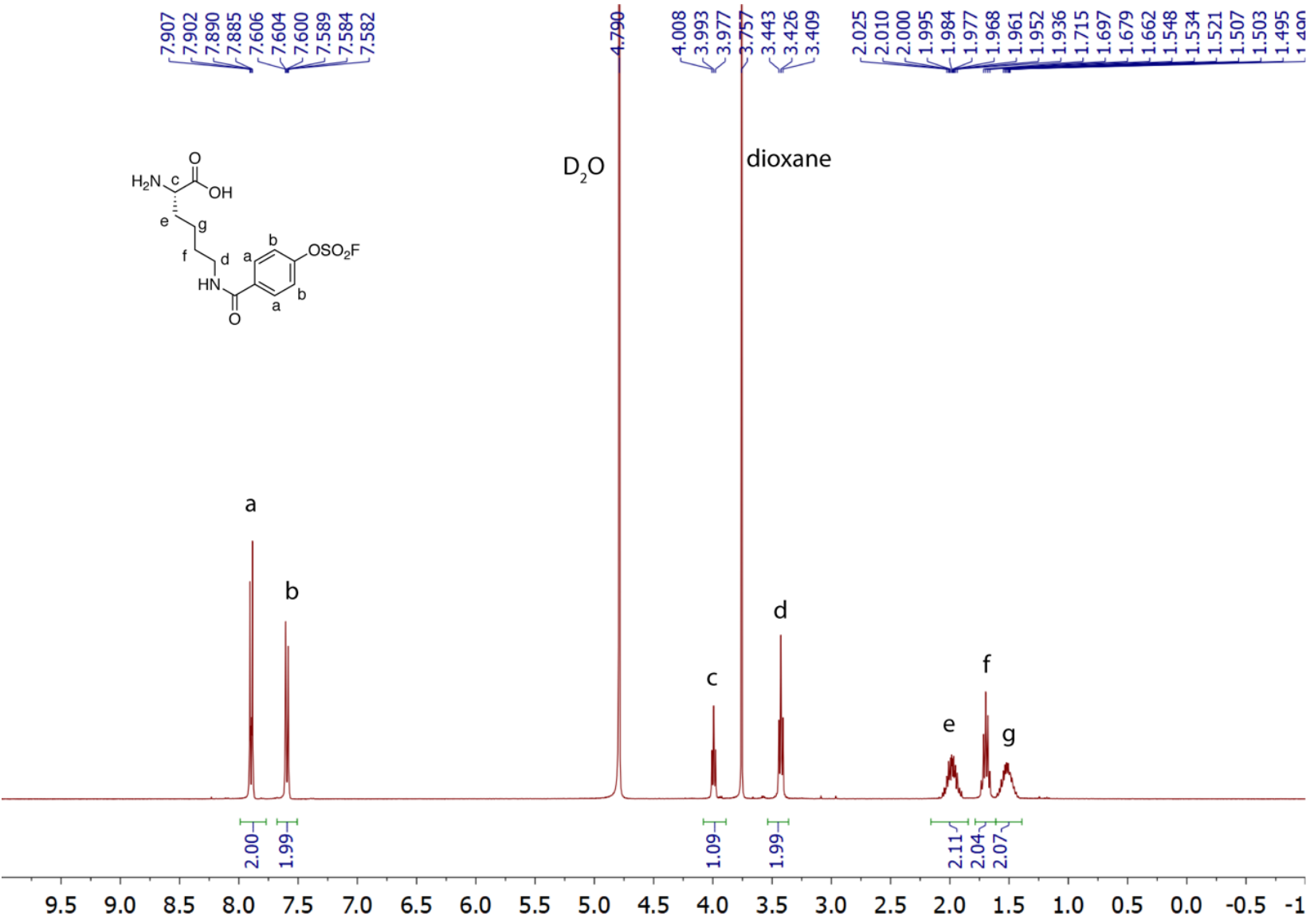
${ }^{13}$ C NMR

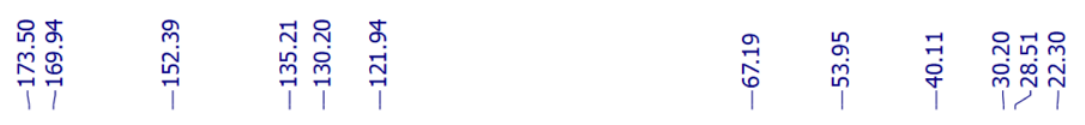
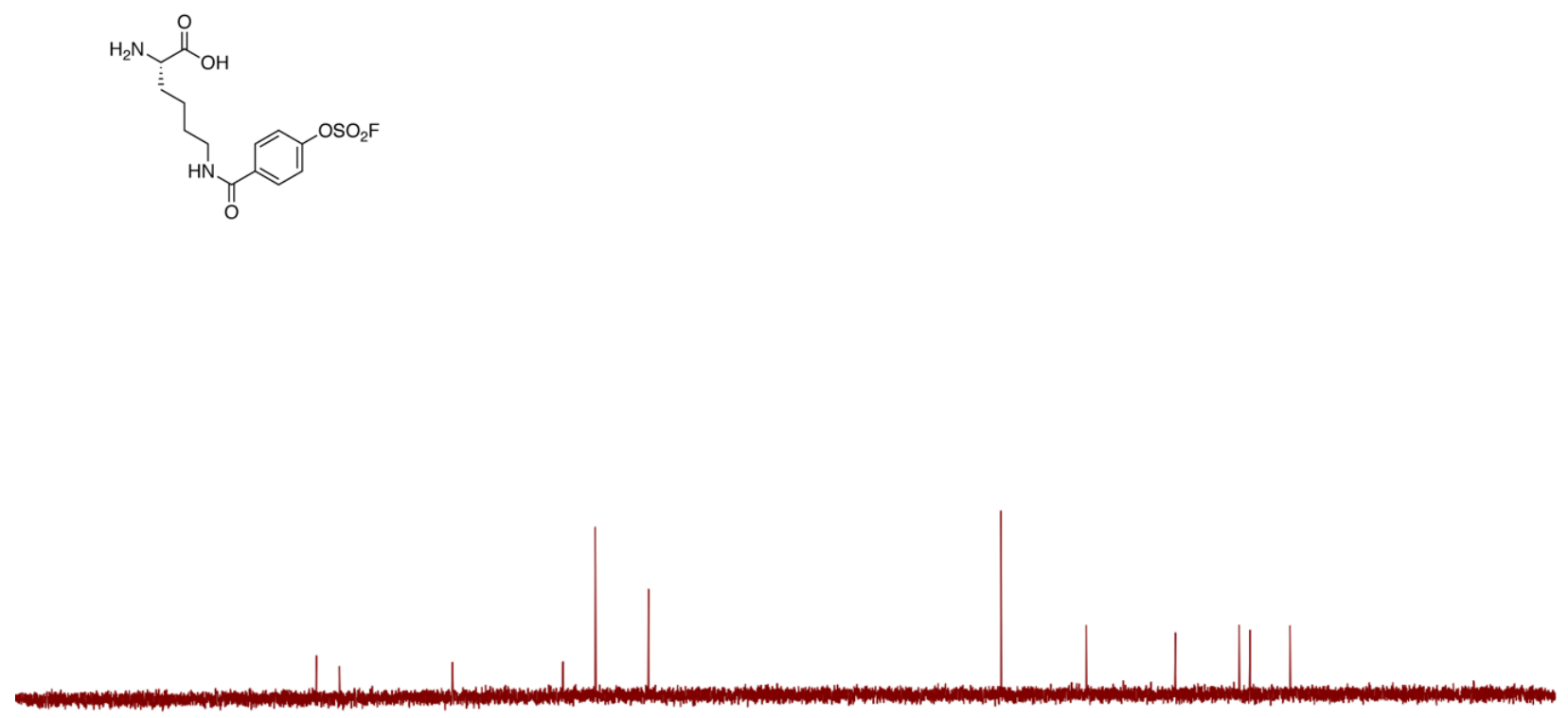

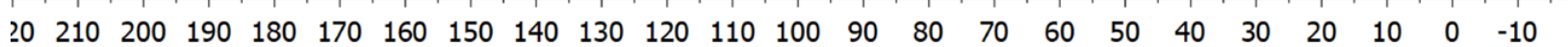




\section{Library construction and FSKRS mutant selection}

To screen an efficient synthetase for the incorporation of FSK, the primers MaPyIRS Ndel to MaPyIRS Pstl were used to randomize the active site of PyIRS and create the library for FSK screening. The selection of an orthogonal synthetase for FSK incorporation was carried out by following the procedures described previously. ${ }^{3-4}$ Candidate hits were recloned to $\mathrm{pEVOL}$ plasmid with primers HRpEVOL-For and HRpEVOL-Rev followed by investigating the incorporation efficiency into pBAD-EGFP (182TAG). The incorporation efficiency for the hits were compared by measuring the green fluorescence intensity (excitation at $485 \mathrm{~nm}$, emission at $528 \mathrm{~nm}$ ) normalized to $\mathrm{OD}$ at $600 \mathrm{~nm}$. Four candidate hits were identified with the mutations shown below.

\begin{tabular}{|c|l|}
\hline Number & AA mutations \\
\hline 1 & Y126G/M129AN168F/H227T/Y228P/L229I \\
\hline 2 & Y126G/M129A/V168F/H227S/Y228P/L229V \\
\hline 3 & Y126G/M129AN168F/H227I/Y228P \\
\hline 4 & Y126G/M129A/V168F/H227S/Y228P/L229I \\
\hline
\end{tabular}

Incorporation of FSK into EGFP (182TAG), sfGFP (151TAG), sfGFP (2TAG) pBAD-sfGFP (2TAG), pBAD-sfGFP (151TAG) or pBAD-EGFP (182TAG) was co-transformed with pEVOL-FSKRS into DH10b, and plated on LB argar plate supplemented with $50 \mu \mathrm{g} / \mathrm{mL}$ kanamycin and $34 \mu \mathrm{g} / \mathrm{mL}$ chloramphenicol. A single colony was picked and inoculated into $1 \mathrm{~mL}$ $2 x Y T$ ( $5 \mathrm{~g} / \mathrm{L} \mathrm{NaCl}, 16 \mathrm{~g} / \mathrm{L}$ Tryptone, $10 \mathrm{~g} / \mathrm{L}$ Yeast extract). The cells were left grown $37{ }^{\circ} \mathrm{C}, 220$ rpm to an OD 0.5, with good aeration for overnight. Next morning, the cells were diluted 10 times in fresh 2 xYT supplemented with relevant antibiotics, $0.2 \%$ arabinose with or without $1 \mathrm{mM} \mathrm{FSK}$. The cells were then induced at either $30^{\circ} \mathrm{C}$ for $6 \mathrm{hr}$ or $18{ }^{\circ} \mathrm{C}$ for overnight. The fluorescence was checked by a plate reader as described above.

\section{General incorporation of FSK into proteins for expression and purification}

For the incorporation of FSK into ubiquitin (6TAG), ubiquitin (18TAG), 7D12 (30TAG), and 7D12 (31TAG), the procedure of transformation is the same as described above. After transformation, a single colony was picked and left grown at $37^{\circ} \mathrm{C}, 220 \mathrm{rpm}$ for overnight. Next morning, the cell culture was diluted 100 times and then regrown to an OD 0.5 in 30 to $100 \mathrm{~mL}$ scale, with good aeration and the relevant antibiotic selection. Then the medium was added with $0.2 \%$ arabinose with or without $1 \mathrm{mM} \mathrm{FSK}$, and the expression were carried out at $18{ }^{\circ} \mathrm{C}, 220 \mathrm{rpm}$ for $18 \mathrm{hr}, 18^{\circ} \mathrm{C}$, or $6 \mathrm{hr}$ at $30^{\circ} \mathrm{C}$. The IMAC chromatography was used for protein purification. And the procedure was done as described elsewhere. ${ }^{1}$

\section{Utilization of FSK and FSY into ecGST, sjGST and their mutants for protein cross-linking} in $E$. coli

For probing ecGST or sjGST and their mutants' cross-linking in living E. coli bacterial cells. pBADecGST WT, pBAD-ecGST (86TAG), pBAD-ecGST (65TAG), pBAD-ecGST (86TAG/92A), pBADecGST (86TAG/92A/72A), or sjGST WT, sjGST (97TAG), sjGST (97TAG/44A, S, T, H, or Y) was was co-transformed with either pEVOL-FSYRS or pEVOL-FSKRS into DH10b cells. FSY or FSK was added with $0.2 \%$ arabinose respectively to the cells for induction when the cells were grown to an OD around 0.5 . The cells were grown for protein expression at $37^{\circ} \mathrm{C}$ for $6 \mathrm{hr}$, which then were harvested by centrifugation with a benchtop centrifuge and treated with 2xSDS loading dye 
containing $100 \mathrm{mM}$ DTT, and boiled for 5 mins at $95{ }^{\circ} \mathrm{C}$. The dimerization of GST due to cross linking was monitored by Western blot using anti-his antibody.

\section{In vitro cross-linking of 7D12 and EGFR}

To explore in vitro cross-linking of 7D12 and EGFR, purified $2 \mu \mathrm{M}$ 7D12 WT, 7D12(30FSK) or 7D12(31FSK) was incubated with $500 \mathrm{nM}$ recombinant human EGFR protein respectively (Abcam, Cat\# ab155726) in $15 \mu \mathrm{L} 1 \mathrm{xPBS}, \mathrm{pH} 7.4$. After incubation at $37^{\circ} \mathrm{C}$ for $16 \mathrm{~h}$, the samples were treated with a final $1 \times$ SDS loading dye and boiled for 5 mins at $95{ }^{\circ} \mathrm{C}$. The cross-linking was investigated by running Coomassie blue SDS-PAGE or Western blot with 1:10000 anti-his antibody.

\section{In cellular cross-linking of 7D12 and EGFR}

For direct cross-linking of 7D12 to A431 mammalian cells which overexpressed EGFR, A431 cells were seeded in 24-well plate $\left(2 \times 10^{5}\right.$ cells per well $)$ and cultured overnight at $37^{\circ} \mathrm{C}$. The cells were treated with $1 \mu \mathrm{M}$ 7D12 and 7D12(31TAG) for 1, 2, 4, 8 and $12 \mathrm{~h}$. After digestion with trypsin, the cells were collected by centrifugation at $300 \mathrm{~g}$ for $5 \mathrm{~min}$ and lysed by adding $100 \mu \mathrm{L}$ RIPA Buffer with 1x protease inhibitor cocktail. The samples were separated on SDS-PAGE and subjected to Western-blot detection with 1:10000 anti-his antibody. Anti-GAPDH antibody was used as a reference protein.

\section{Genetic incorporation of FSK into Hela GFP (182TAG)}

The plasmid pNEU-FSKRS $(1 \mu \mathrm{g})$ was transfected into Hela-GFP 182(TAG) cells with $3 \mu \mathrm{L}$ polyethylenimine (PEI) in $2 \mathrm{~mL}$ RPMI 1640 media when the cells population reached $80 \%$ confluence. A blank Hela-GFP 182(TAG) cell group was used as a negative control. The cells were treated with or without $1 \mathrm{mM}$ FSK $6 \mathrm{hr}$ after transfection and cultured for additional $48 \mathrm{hr}$. The cells were washed with $1 \mathrm{xPBS}$ for one time and subjected for microscope image after which will be harvested and ran Western blot using anti-GFP antibody. Anti-GAPDH antibody was used as a reference protein.

\section{Genetic incorporation of FSK into ecGST mutants in mammalian cells}

For probing protein cross-linking in mammalian cells. The plasmid pNEU-FSKRS $(1.5 \mu \mathrm{g})$ was co-transfected with $1 \mu \mathrm{g}$ pCDNA 3.1 ecGST WT, $1.5 \mu \mathrm{g}$ ecGST (86TAG), $1.5 \mu \mathrm{g}$ ecGST(86TAG/92A), and $1.5 \mu \mathrm{g}$ ecGST(86TAG/92A/72A) respectively into HEK (293T) cells with $9 \mu \mathrm{L}$ polyethylenimine (PEI) in $2 \mathrm{~mL}$ DMEM media when the cells population reached $80 \%$ confluence. The cells were treated with or without $1 \mathrm{mM} \mathrm{FSK} 6 \mathrm{hr}$ after transfection and cultured for additional $48 \mathrm{hr}$. The cells were harvested and ran Western blot using anti-His antibody. AntiGAPDH antibody was used as a reference protein.

\section{Mass spectrometry}

Mass spectrometric measurements were performed as previously described. ${ }^{5}$ Briefly for electrospray ionization mass spectrometry, mass spectra of intact proteins were obtained using a QTOF Ultima (Waters) mass spectrometer, operating under positive electrospray ionization (+ESI) mode, connected to an LC-20AD (Shimadzu) liquid chromatography unit. Protein samples were separated from small molecules by reverse phase chromatography on a Waters Xbridge BEH C4 column (300 $\AA, 3.5 \mu \mathrm{m}, 2.1 \mathrm{~mm} \times 50 \mathrm{~mm}$ ), using an acetonitrile gradient from $30-71.4 \%$, with $0.1 \%$ formic acid. Each analysis was 25 min under constant flow rate of $0.2 \mathrm{~mL} / \mathrm{min}$ at RT. Data were acquired from m/z 350 to 2500 , at a rate of $1 \mathrm{sec} / \mathrm{scan}$. Alternatively, spectra were acquired by Xevo G2-S QTOF on a Waters ACQUITY UPLC Protein BEH C4 reverse-phase column (300 A, $1.7 \mu \mathrm{m}, 2.1 \mathrm{~mm} \times 150 \mathrm{~mm}$ ). An acetonitrile gradient from 5\%-95\% was used with $0.1 \%$ formic acid, over a run time of $5 \mathrm{~min}$ and constant flow rate of $0.5 \mathrm{~mL} / \mathrm{min}$ at RT. Spectrum were acquired from m/z 350 to 2000, at a rate of $1 \mathrm{sec} / \mathrm{scan}$. The spectra were deconvoluted 
using maximum entropy in MassLynx. For tandem mass spectrometry, analysis and sequencing of peptides were carried out using a Q Exactive Orbitrap interfaced with Ultimate 3000 LC system. Data acquisition by $Q$ Exactive Orbitrap was as follows: $10 \mu \mathrm{L}$ of trypsin-digested protein was loaded on an Ace UltraCore super C18 reverse-phase column (300 A, $2.5 \mu \mathrm{m}, 75 \mathrm{~mm} \times 2.1 \mathrm{~mm})$ via an autosampler. An acetonitrile gradient from $5 \%-95 \%$ was used with $0.1 \%$ formic acid, over a run time of $45 \mathrm{~min}$ and constant flow rate of $0.2 \mathrm{~mL} / \mathrm{min}$ at RT. MS data were acquired using a data-dependent top10 method dynamically choosing the most abundant precursor ions from the survey scan for HCD fragmentation using a stepped normalized collision energy of $28,3035 \mathrm{eV}$. Survey scans were acquired at a resolution of 70,000 at $\mathrm{m} / \mathrm{z} 200$ on the $Q$ Exactive. Theoretical patterns of isotopic patterns of peptides were calculated using UCSF MS-ISOTOPE ${ }^{6}$ or enviPat Web 2.1. ${ }^{7}$ Cross-linked peptides were searched with pLink2 and OpenUaa. ${ }^{8,9}$ 


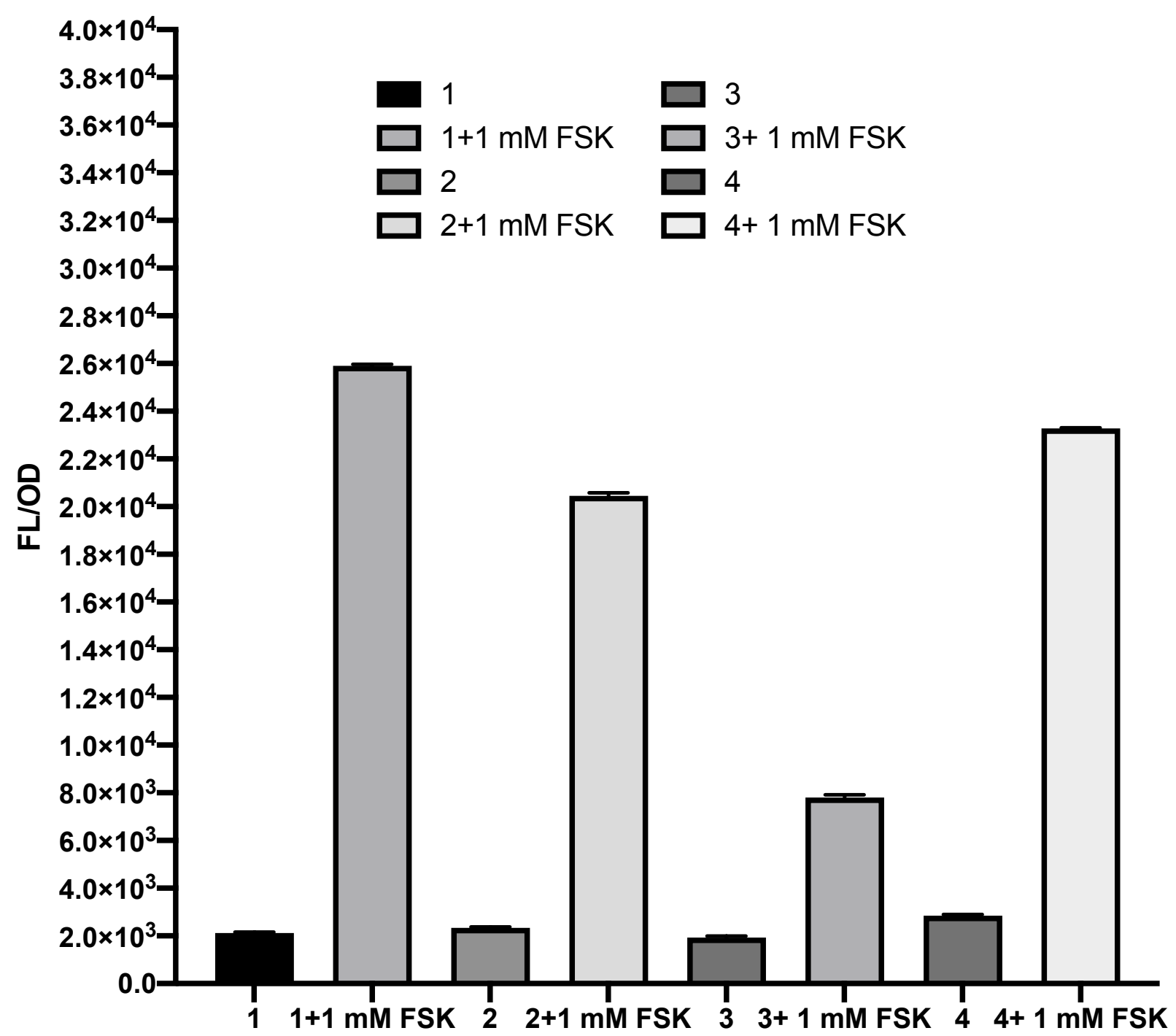

Figure S1. Comparison of FSK incorporation efficiency into EGFP at $18{ }^{\circ} \mathrm{C}$ for $24 \mathrm{~h}$. The four identified synthetase hits indicated by numbers were separately used with tRNA ${ }^{\text {Pyl }}$ to incorporate FSK into EGFP (182TAG). EGFP expression was induced at $18{ }^{\circ} \mathrm{C}$ for $24 \mathrm{~h}$, in the presence or absence of $1 \mathrm{mM}$ FSK in growth media. Cell fluorescence intensity normalized to cell $\mathrm{OD}_{600}$ was compared. Error bars represent s.e.m., $\mathrm{n}=3$ independent experiments. 


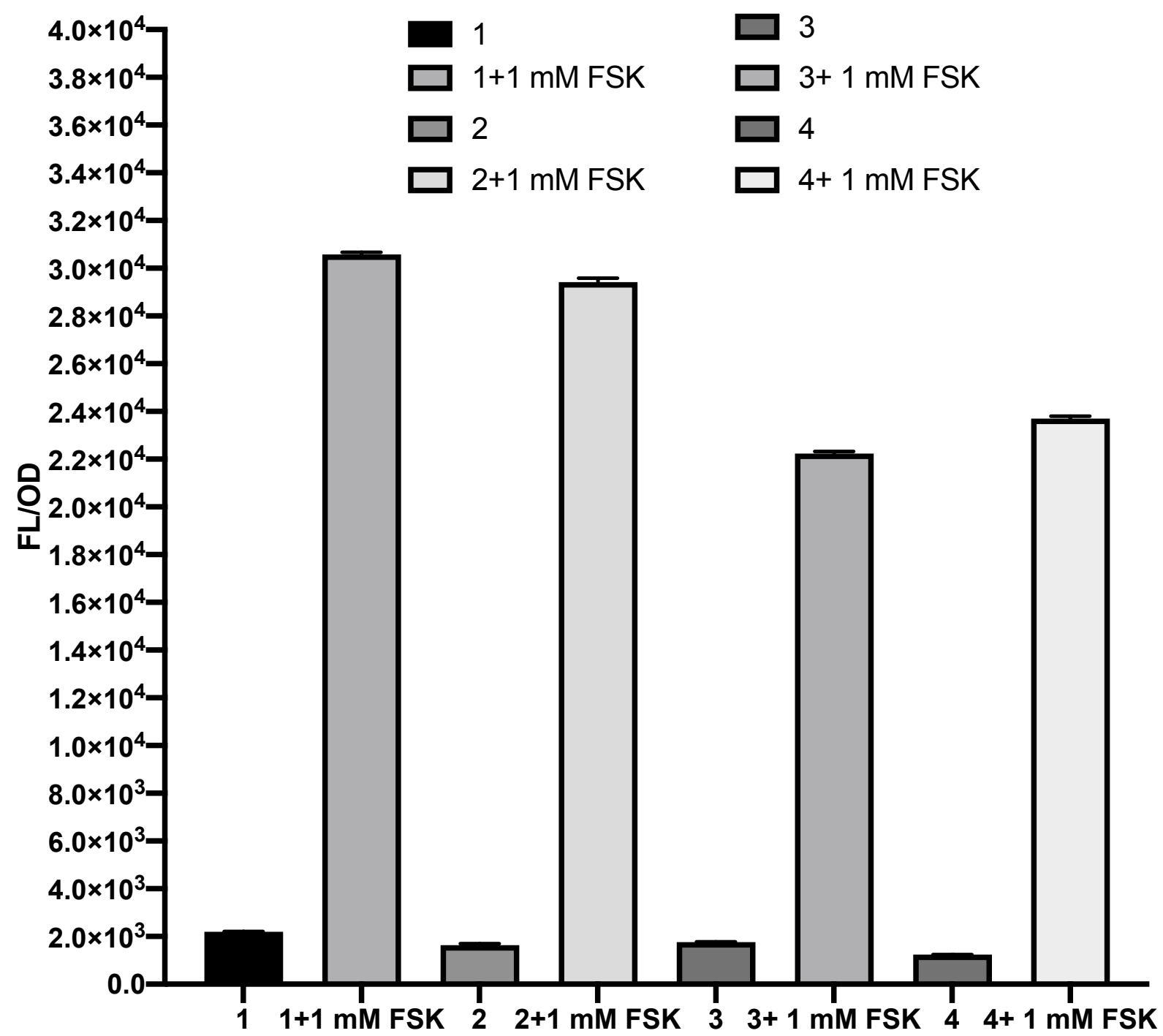

Figure S2. Comparison of FSK incorporation efficiency into EGFP at $30^{\circ} \mathrm{C}$ for $6 \mathrm{~h}$. The four identified synthetase hits indicated by numbers were separately used with tRNA ${ }^{\text {Pyl }}$ to incorporate FSK into EGFP (182TAG) in E. coli. EGFP expression was induced at $30{ }^{\circ} \mathrm{C}$ for $6 \mathrm{~h}$, in the presence or absence of $1 \mathrm{mM}$ FSK in growth media. Cell fluorescence intensity normalized to cell $\mathrm{OD}_{600}$ was compared. Error bars represent s.e.m., $\mathrm{n}=3$ independent experiments. 


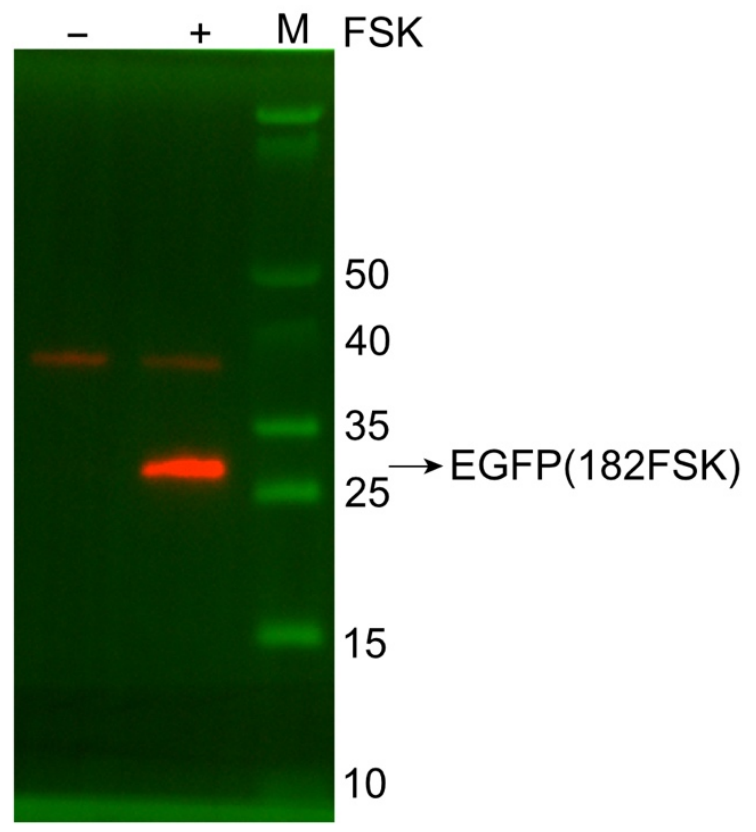

Figure S3. Western blot analysis of incorporation of FSK into EGFP (182TAG). FSKRS/tRNA ${ }^{\text {Pyl }}$ were co-transformed with pBAD-EGFP(182TAG) into $E$. coli, and cells were grown with or without $1 \mathrm{mM}$ FSK. Cell lysates were separated, and an anti-His antibody was used to detect the Hisx6 tag appended at the C-terminus of EGFP. 


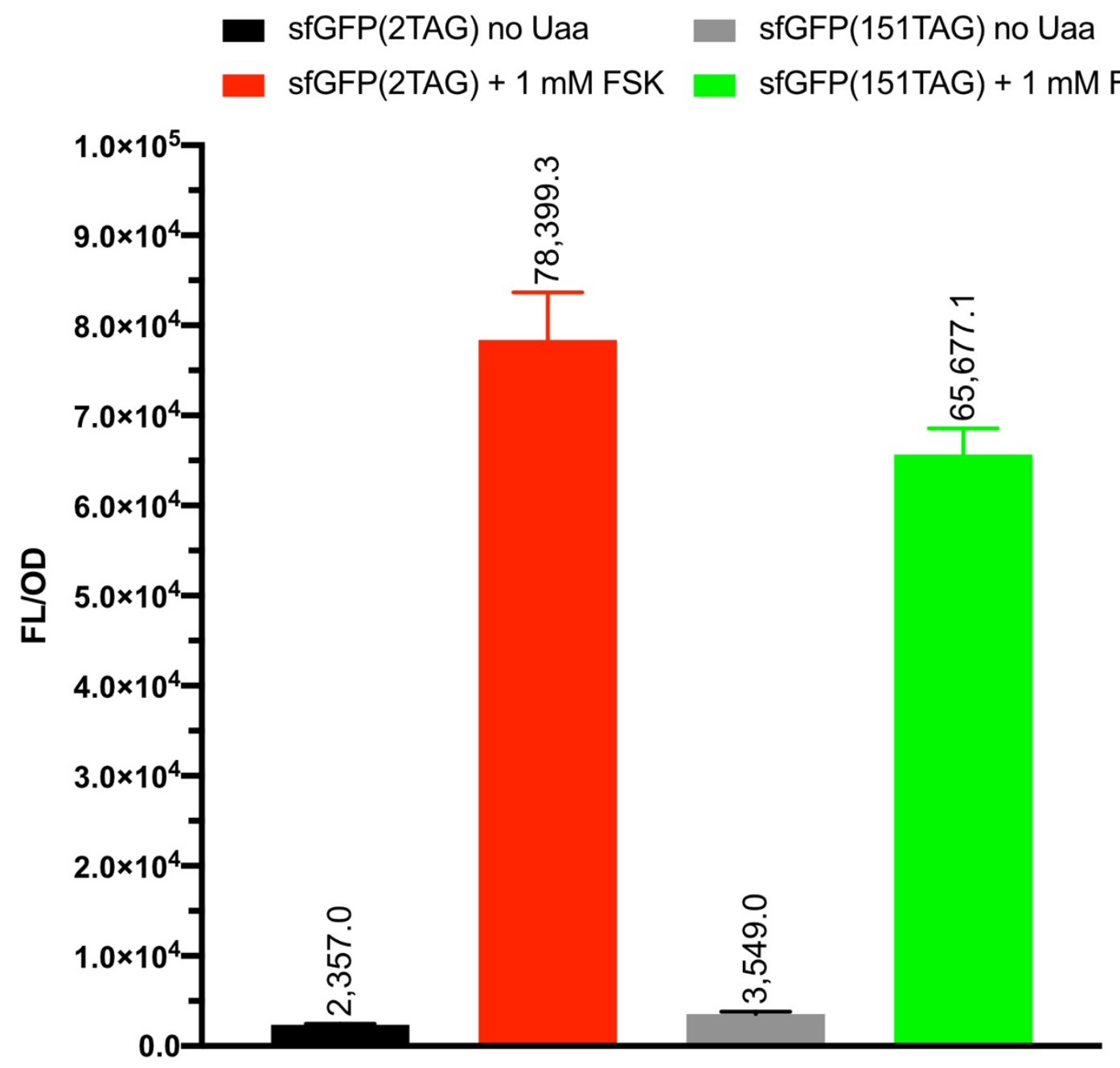

Figure S4. Incorporation of FSK into sfGFP (2TAG) and sfGFP(151TAG). pEVOL-FSKRS was co-transformed with pBAD-sfGFP(2TAG) or pBAD-sfGFP(151TAG) into E. coli DH10b cells, respectively. Cells were grown with or without $1 \mathrm{mM} \mathrm{FSK}$. sfGFP expression was detected using a plate reader (485 $\mathrm{nm}$ excitation wavelength, $528 \mathrm{~nm}$ emission wavelength). The plot represented the sfGFP fluorescence intensity after normalization to bacterial growth at optical density $600 \mathrm{~nm}$. Error bars represent s.e.m., $\mathrm{n}=3$ independent experiments. 


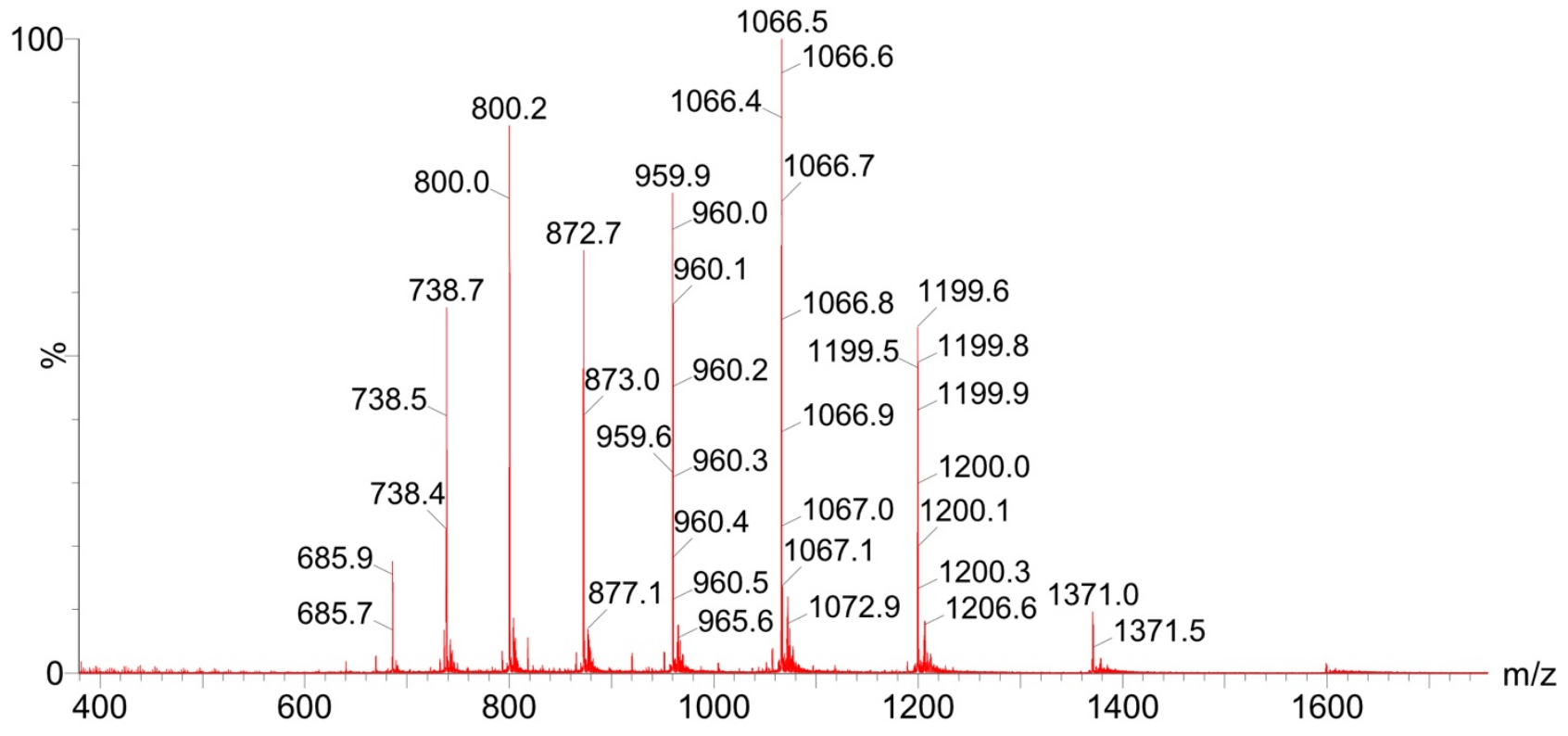

Figure S5. M/Z mass spectrum of Ub (6FSK). 


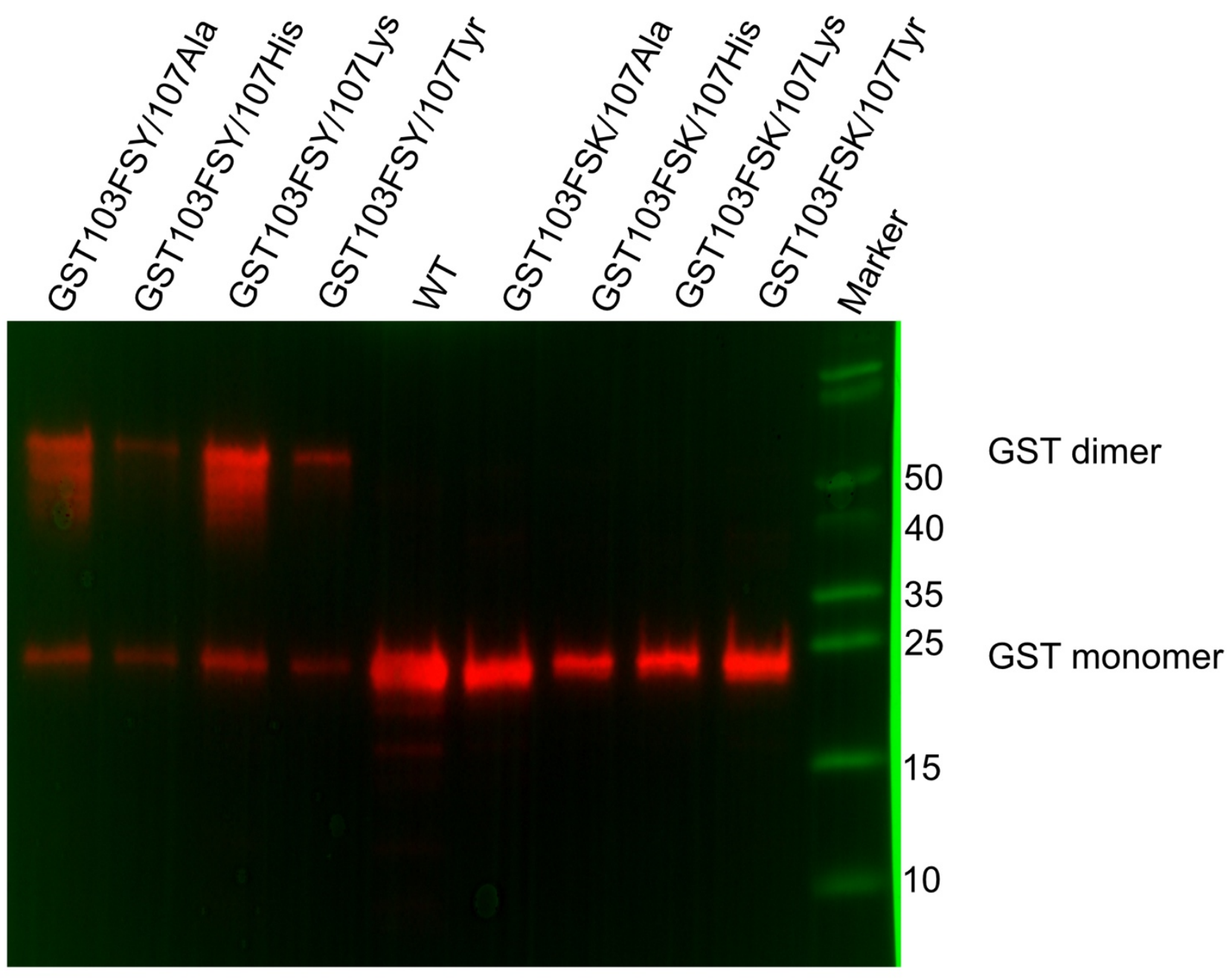

Figure S6. Comparison of the FSY- and FSK-mediated GST cross-linking in short distance proximity. The pEVOL-FSYRS or pEVOL-FSKRS was co-expressed with ecGST (103TAG/107Ala), ecGST (103TAG/107His), ecGST (103TAG/107Lys), ecGST (103TAG/107Tyr), respectively in E. coli in the presence of $1 \mathrm{mM}$ FSK or FSY at $37^{\circ} \mathrm{C}$ for $6 \mathrm{~h}$. The WT GST was used as a negative control. The GST dimeric cross-linking was detected through Western blot of $E$. coli cell lysate by using anti-His antibody to detect the Hisx 6 tag appended at the C-terminus of GST. ecGST has His at site 106, which could also be cross-linked by FSY103 in the first four lanes. 

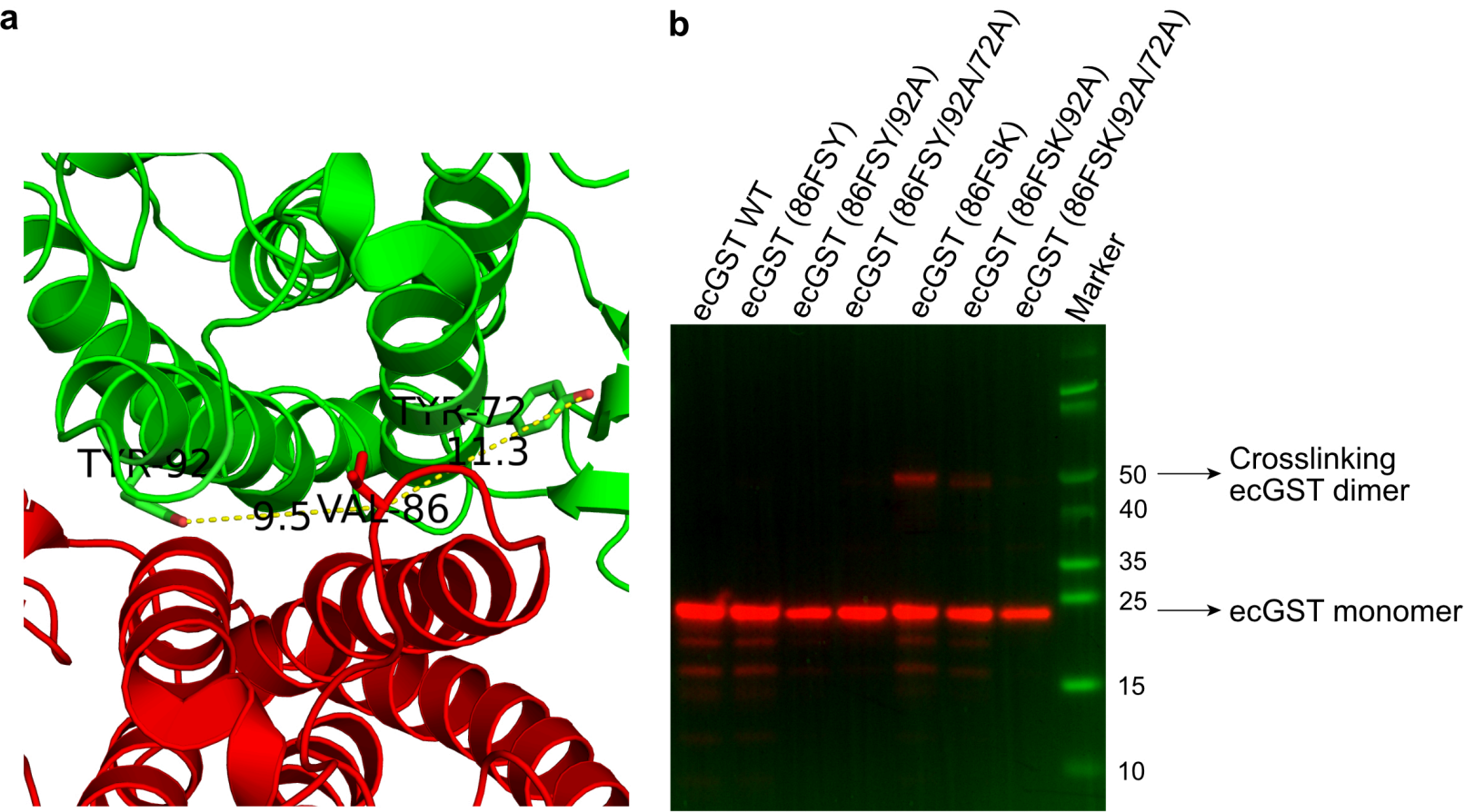

Figure S7. Comparison of the FSY- and FSK- mediated E. coli GST cross-linking at site 86. The pEVOL-FSYRS or pEVOL-FSKRS was co-expressed with ecGST WT or pBAD-GST (86TAG) in the presence of $1 \mathrm{mM}$ FSK or FSY at $37^{\circ} \mathrm{C}$ for $6 \mathrm{~h}$. The WT GST was used as a negative control. The GST dimer cross-linking was detected with Western blot by using an anti-His antibody. 


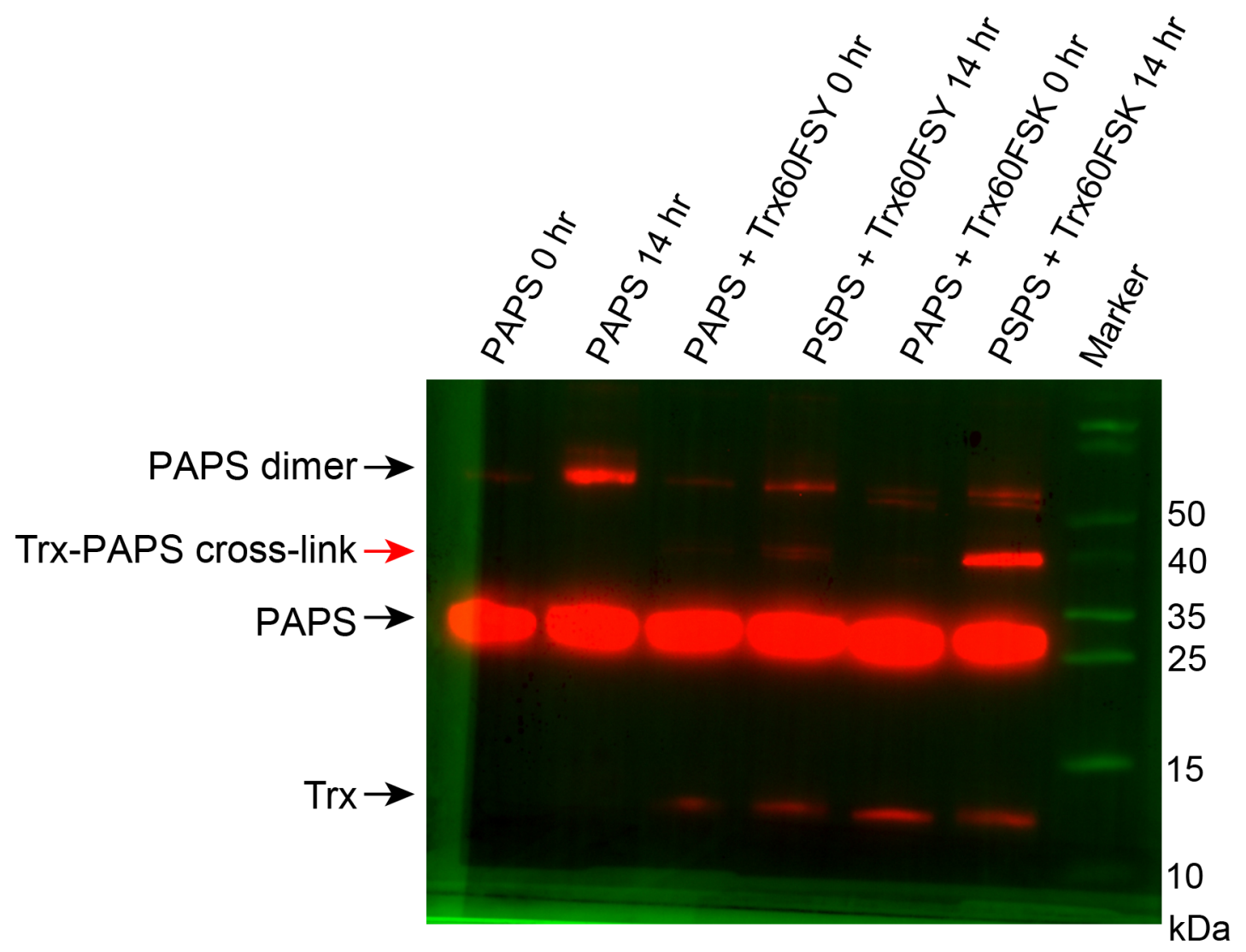

Figure S8. Comparison of the cross-linking efficiency of FSK and FSY in mediating Trx and PAPS cross-linking. An anti-His antibody was used to detect both Trx and PAPS in the Western blot. 


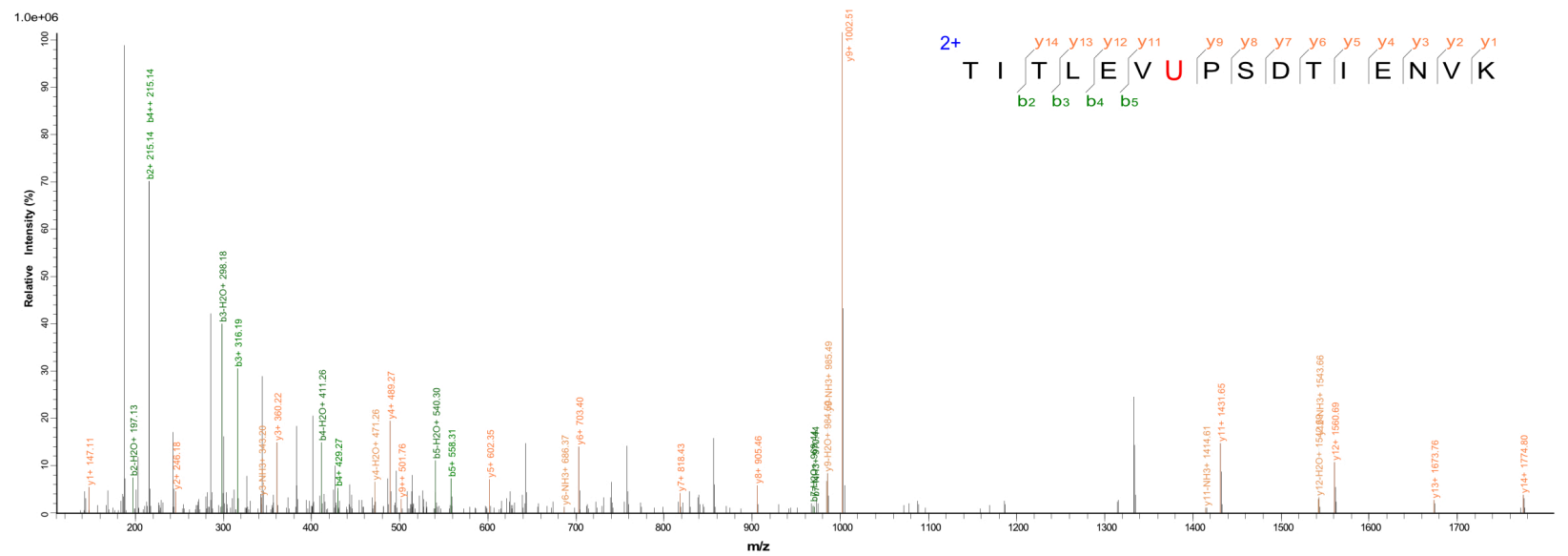

Figure S9. Tandem mass spectrum of the intact FSK-incorporated peptide of ubiquitin. $U$ represents FSK incorporated at site 18 of ubiquitin. 


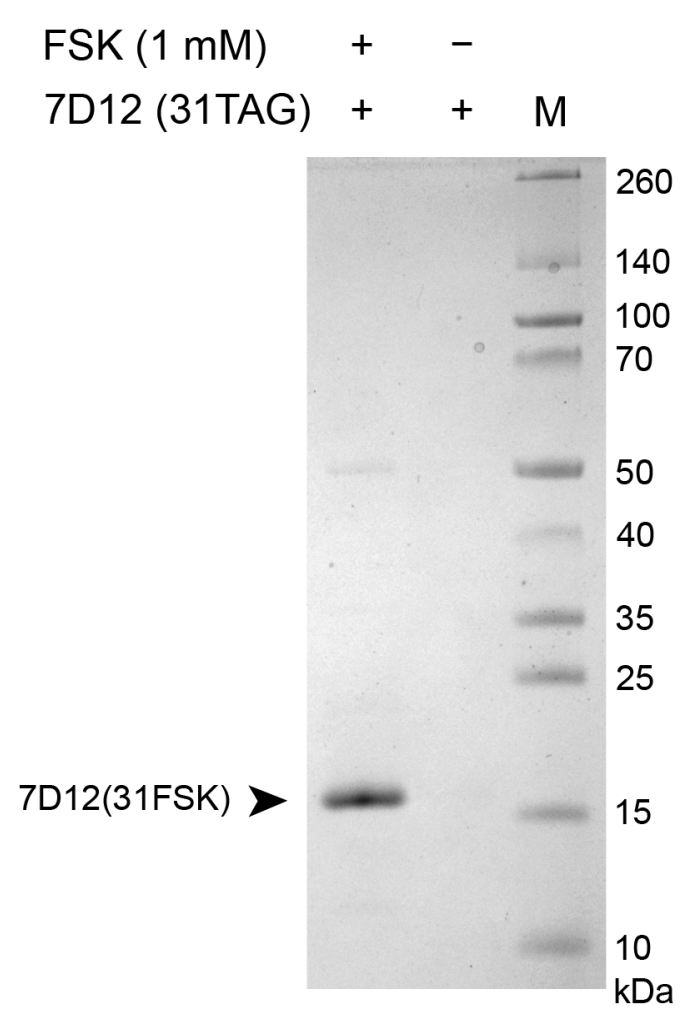

Figure S10. SDS-PAGE analysis of purified nanobody 7D12 (31FSK). In the absence of 1 $\mathrm{mM}$ FSK during expression, no full-length nanobody was produced. 
a

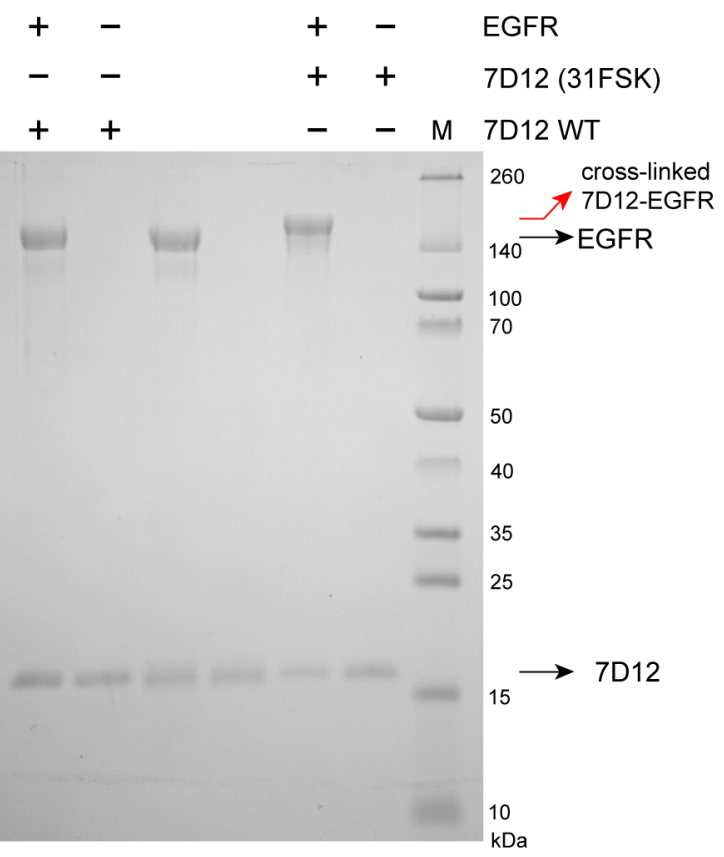

b

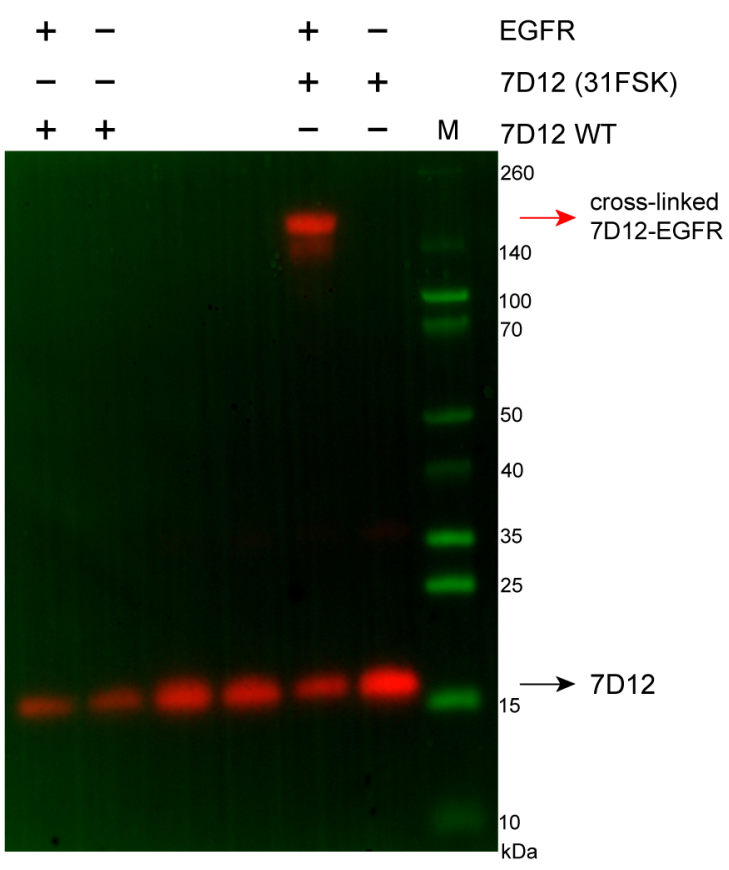

Figure S11. SDS-PAGE and Western blot analysis of covalent cross-linking of nanobody 7D12 (WT) and 7D12 (31FSK) to EGFR in vitro. (a) SDS-PAGE. (b) Western blot using an antiHis6 antibody to detect nanobody 7D12. 

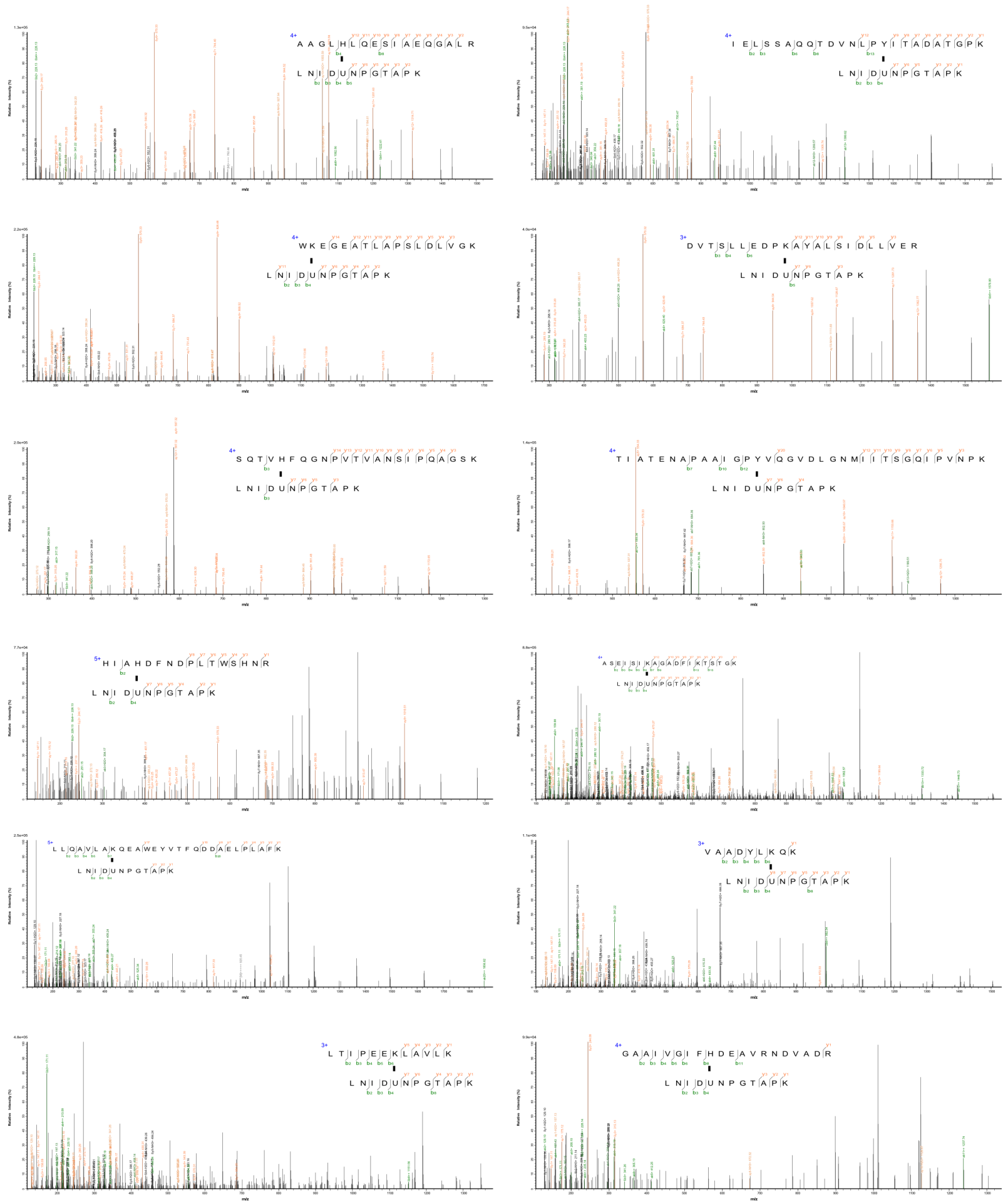

Figure S12. Tandem mass spectra of cross-linked peptides identified from Trx (62FSK). 

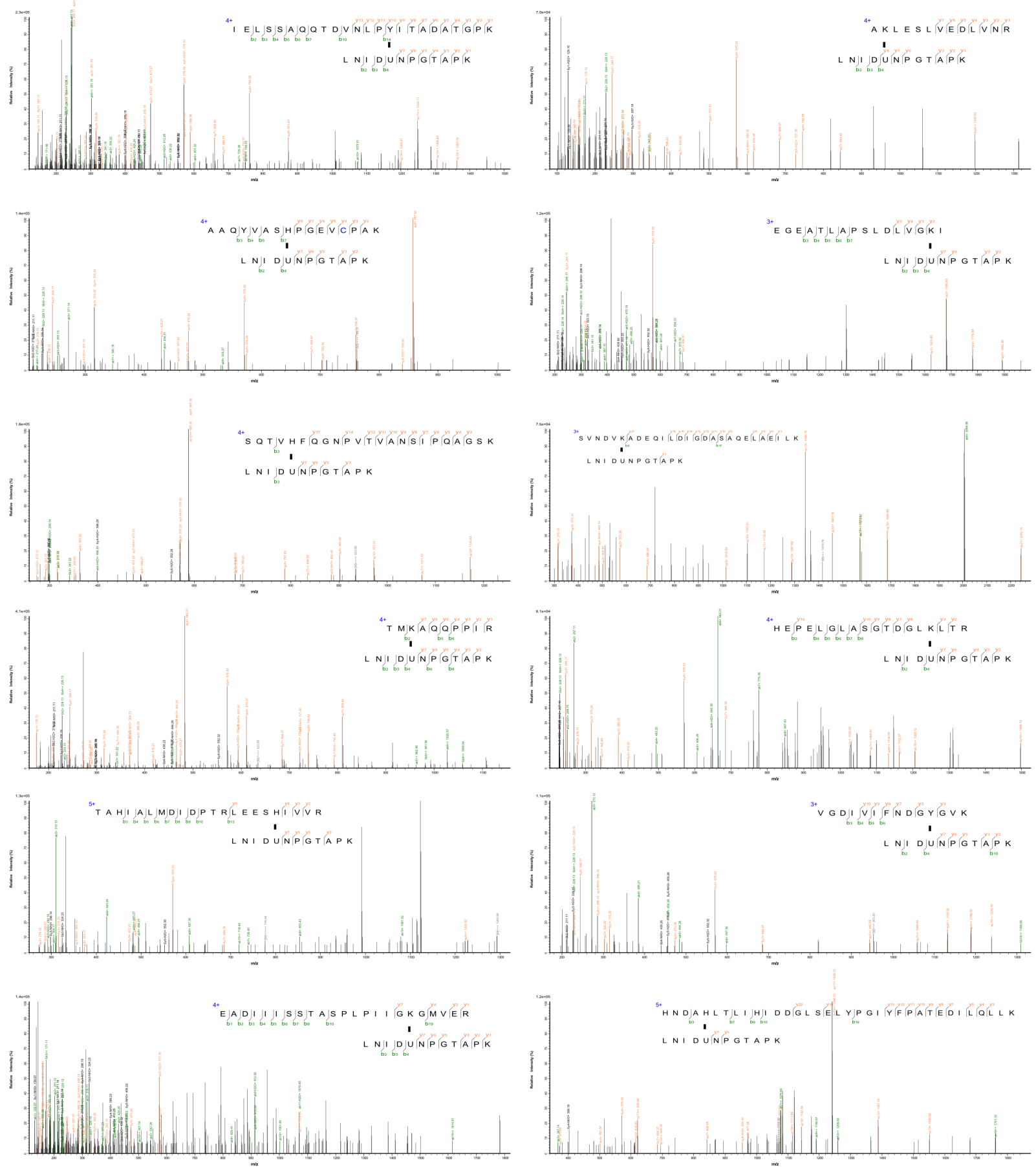

Figure S13. Tandem mass spectra of cross-linked peptides identified from Trx (62FSY). 


\section{Supplementary Reference}

1. Liu, J.; Li, S.; Aslam, N. A.; Zheng, F.; Yang, B.; Cheng, R.; Wang, N.; Rozovsky, S.; Wang, P. G.; Wang, Q.; Wang, L., Genetically Encoding Photocaged Quinone Methide to Multitarget Protein Residues Covalently in Vivo. J. Amer. Chem. Soc. 2019, 141 (24), 9458-9462.

2. Zhou, H.; Mukherjee, P.; Liu, R.; Evrard, E.; Wang, D.; Humphrey, J.M.; Butler, T.W.; Hoth, L.R.; Sperry, J.B.; Sakata, S.K.; Helal, C.J.; am Ende, C.W. Org. Lett. 2018, 20(3), 812-815.

3. Liu, J.; Zheng, F.; Cheng, R.; Li, S.; Rozovsky, S.; Wang, Q.; Wang, L., Site-Specific Incorporation of Selenocysteine Using an Expanded Genetic Code and Palladium-Mediated Chemical Deprotection. J. Amer. Chem. Soc. 2018, 140 (28), 8807-8816.

4. Liu, J.; Cheng, R.; Wu, H.; Li, S.; Wang, P. G.; DeGrado, W. F.; Rozovsky, S.; Wang, L., Building and Breaking Bonds via a Compact S-Propargyl-Cysteine to Chemically Control Enzymes and Modify Proteins. Angew. Chem. Int. Ed. Engl. 2018, 57 (39), 12702-12706.

5. Liu, J.; Chen, Q.; Rozovsky, S., Utilizing Selenocysteine for Expressed Protein Ligation and Bioconjugations. J. Amer. Chem. Soc. 2017, 139 (9), 3430-3437.

6. Baker, P. R., Clauster, K.R., http://prospector.ucsf.edu.

7. Loos, M.; Gerber, C.; Corona, F.; Hollender, J.; Singer, H., Accelerated Isotope Fine Structure Calculation Using Pruned Transition Trees. Anal. Chem. 2015, 87 (11), 5738-5744.

8. Chen, Z.; Meng, J.; Cao, Y.; Yin, J.; Fang, R.; Fan, S.; Liu, C.; Zeng, W.; Ding, Y.; Tan, D.; Wu, L.; Zhou, W.; Chi, H.; Sun, R.; Dong, M.; He, S. A high-speed search engine pLink 2 with systematic evaluation for proteome-scale identification of crosslinked peptides. Nat. Commun. 2019, 10, 3404.

9. Liu, C.; Wu, T.; Shu, X.; Li, S.; Wang, D.R.; Wang, N.; Zhou, R.; Yang, H.; Jiang, H.; Hendriks, I.A.; Gong, P.; Zhang, L.; Nielsen, M.L.; Li, K.; Wang, L.; Yang, B. Identification of Protein Direct Interactome with Genetic Code Expansion and Search Engine OpenUaa. Adv. Biology 2021, 5, 2000308. 